\title{
Getting on the Board: The Presence of Women in Political Science Journal Editorial Positions
}

\author{
Mary Stegmaier, University of Missouri \\ Barbara Palmer, Baldwin-Wallace College \\ Laura van Assendelft, Mary Baldwin College
}

ABSTRACT Although the overall representation of women in the field of political science has increased gradually over the last several decades, most gains are being achieved at junior levels. When considering the status of women in the profession, it is instructive to incorporate information on the presence of women in editorial positions at top-ranked political science journals. Our 2010 snapshot of women editors in the top 50 journals in the field finds that on average, women are reasonably well represented in editorial positions in proportion to the ranks they hold in the profession overall and at PhD-granting institutions; however, substantial variation exists across journals. Our discussion of the rolemodel effect and the gatekeeping power of editors suggests that greater inclusion of women and others who bring different perspectives to research could result in a more vibrant range of research topics and methodological approaches published in a journal.

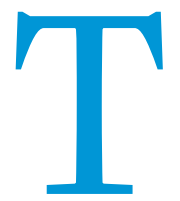

he overall representation of women in the field of political science has gradually, but slowly, increased. The American Political Science Association (APSA) reports an increase of women from $19 \%$ in 1991 to $29 \%$ by 2010 , with most gains being achieved at the junior levels (APSA 2010; Sedowski and Britnall 2007). As table 1 shows, in $2010,40 \%$ of assistant professors, $30 \%$ of associate professors, and $19 \%$ of full professors were women. Although the "chilly climate" for women in political science appears to be warming, chronic underrepresentation of women continues. Decades

Mary Stegmaier is a teaching assistant professor at the Truman School of Public Affairs at the University of Missouri. Her research focuses on the impact of economic conditions on voting behavior and election outcomes in the United States and abroad. Among other courses, she teaches classes on the status of women in politics and the workforce. She can be reached at stegmaierm@missouri.edu.

Barbara Palmer is an associate professor and legal studies coordinator at BaldwinWallace College. In addition to an interest in the status of women in the profession, her current research explores congressional elections and the success of women candidates, gerrymandering and redistricting, and the history of third parties in the United States. With her co-author, Dennis Simon, she received the Marian Irish Award for Best Paper on Women \& Politics presented at the 2010 Southern Political Science Association Annual Meeting. She serves on the board of Running Start, a nonprofit organization that encourages and trains high school girls to run for political office. She can be reached at bpalmer@bw.edu.

Laura van Assendelft is a professor of political science at Mary Baldwin College. Her research interests include state and local politics and women and politics. She recently co-authored Women, Politics, and American Society, Fifth Edition. She has also served on the APSA Committee on the Status of Women and as a past chair of the SPSA Committee on the Status of Women. She can be reached at Ivanasse@mbc.edu. of research on the status of women attempt to explain this limited progress. Most recently, APSA's work through its Committee on the Status of Women and workshops on women's advancement in political science identify four primary barriers that persist. First, there is a "leaking pipeline"; women are leaving the profession for alternative careers. Second, for women trying to balance work and family, childbearing years typically correspond with the heavy academic demands associated with tenure and promotion. This can make it difficult for parents to meet the research expectations for tenure, which results in some women leaving academia and others being denied tenure and promotion. Third, the institutional climate is often "inhospitable" to women, failing to provide the mentoring and support needed for women to succeed in the profession. Finally, a culture of research continues to provide maximum reward for single-authorship rather than collaborative research ("Women's Advancement" 2005). These forces combined stagnate the progress made by women, particularly at the senior levels.

Because journal editors and editorial board members are selected based on their demonstrated expertise in a research area, serving in an editorial position is one measure of senior-level professional advancement and success. Editors have a strong influence in determining the direction of the discipline through their decisions on what research is published and what is rejected. Carefully reviewing articles and making editorial decisions is a timeconsuming process that often eats into one's own research time. Thus, taking on this work does not come without costs but affords 
scholars the chance to play a prominent role in the discipline. As such, when we consider the status of women in the profession, it is instructive to incorporate information on the presence of women in editorial positions at top-rated political science journals.

Research on women on the editorial boards of major journals in other disciplines shows a lack of parity among women and men. In the field of medicine, for example, a 2001 article demonstrated that women have increased to $42 \%$ of all medical students, yet in the 12 major medical journals only $25 \%$ had women as editors and an average of only $17 \%$ as board members. (Kennedy et al. 2001). A more recent study on the composition of 93 medical society and journal boards found similar results; $17 \%$ of board members were women (Morton and Sonnad 2007). Research conducted in the field of management in 2004 found that the percentage of women on the editorial boards of 57 journals ranged from zero to $47 \%$, with women composing less than $10 \%$ of editorial board members on 12 journals (Metz and Harzing 2009).

While reports documenting the presence of women on journal boards exist for a few disciplines, no such work exists in political science. Using original data we collected, we address this void by assessing the presence of women serving as editors and on editorial boards of political science journals. We have found that, while women are not well represented among senior faculty in political science, women are relatively well represented given their presence in the discipline, in editorial positions among the topranked political science journals. In other words, the proportion of women as editors, associate editors, and editorial and advisory board members is reasonably close to the proportion of senior women in the field. Our analysis serves as a starting point for continuing discussions about the status of women in political science and for future studies examining changes in editorial board compositions.

\section{OUR DATA}

Using the "relative impact" ranking of political science journals developed by Garand et al. (2009, 699-701), we reviewed journal editorial information from the 50 top-ranked journals by accessing their websites in February and March 2010. ${ }^{1}$ Garand and his colleagues conducted an Internet survey in 2007 of political scientists in the United States, Canada, and the United Kingdom $(N=1,695)$ asking questions that tapped into their assessment of 92 journals in the field. ${ }^{2}$ While Garand and colleagues rank the relative impact of all 92 journals, in this article we focus on the top 50 , as this group provides a wide range of subfields and academic perspectives. The appendix presents the list of the 50 journals included in our analysis, as well as the original data we collected for each journal. The gender of the editor was assumed from first names, and if this was unclear, additional research was done to find a pronoun or photo of the person. We compiled this information for the positions of editor, associate editor, and members of editorial and advisory boards.

\section{THE RELATIVELY GOOD NEWS: THE PRESENCE OF WOMEN IN EDITORIAL POSITIONS}

Table 1 provides an overview of the proportion of women in the profession at the assistant-, associate-, and full-professor ranks in political science in 2010. Because most editors and editorial board members are on the faculty at research universities (Collins et al. 2010), we have also provided statistics on women at $\mathrm{PhD}$-granting institutions. As the table shows, the overall proportions of women
Table 1

Women in the Political Science Profession, 2010

\begin{tabular}{lcc} 
THE PROPORTION OF WOMEN & OVERALL & $\begin{array}{c}\text { AT PHD-GRANTING } \\
\text { INSTITUTIONS }\end{array}$ \\
\hline Assistant Professors & $40 \%$ & $39 \%$ \\
\hline Associate Professors & $30 \%$ & $32 \%$ \\
\hline Full Professors & $19 \%$ & $20 \%$ \\
\hline Senior Professors (Associate \& Full) & $23 \%$ & $25 \%$ \\
\hline At All Ranks & $29 \%$ & $27 \%$ \\
\hline
\end{tabular}

Data provided by the American Political Science Association

in the profession are similar to the proportions of women at $\mathrm{PhD}$ granting institutions.

Table 2 presents the percentage of women in editorial positions in the top 50 political science journals. The row labeled "editors" includes the individuals who serve as the chief editor or the senior editor, co-editors, or individuals listed in the journal as editors. We did not count managing editors because of the variation in their roles and responsibilities. In some cases, the managing editor handles the day-to-day operations of the journal but does not wield any decision-making power. In addition, book review editors were not included in our data. ${ }^{3}$

In general, a small number of people hold the position of editor; 95 people are titled editor among the 50 journals. As table 2 shows, overall, 78 men and 17 women serve as editors, which translates into women holding $18 \%$ of the editorships. Because no journal employs more than one woman as editor, women work as editors at only one-third of these journals ( 17 of 50). Because the scholars serving in these positions are overwhelmingly associate or full professors, comparing these percentages to the percentage of women at these faculty ranks listed in table 1 is useful. Women are $23 \%$ of all senior-level professors overall and $25 \%$ of seniorlevel professors at PhD-granting institutions. This suggests that, although the percentages do not exactly match, women are reasonably well represented as editors of political science journals. ${ }^{4}$

The number of editors for each journal varies across journals. Some just have one editor, while others have two, three, or four. Surprisingly, as the number of editors for a particular journal increases, the number of women decreases. Out of 20 journals that have single editors, women serve as editors for five (25\%), Political Theory, Politics and Society, Annals of the American Academy, Law and Society Review, and International Affairs. Of the 18 journals that have two editors, 11 have two men (61\%), seven (39\%) have a one man and one woman. No journal has two women who serve as editors. Among the seven journals with three editors, five of these (71\%) have no women at all, and two of them, the British Journal of Political Science and the European Journal of International Relations, have two men and one woman; out of the 21 people who serve as editors of these seven journals, only two, or less than $10 \%$, are women. The Journal of Law and Economics has four editors, all men. Political Psychology also has four editors, one of which is a woman. Among the editors of the American Political Science Review, one of the eight editors is a woman. Thirty journals on the top 50 list have multiple editors with women making up $16 \%$ of these 
Table 2

Women in the Top 50 Political Science Journals, 2010

\section{THE PROPORTION OF WOMEN}

Editors $18 \%(17 / 95)$

Editors and Associate Editors 23\% (35/150)

Board Members $26 \%(457 / 1745)$

editors. Seven of these 30 journals, $23 \%$, have an equal representation of men and women, and these journals all have two editors. Whereas most journals in political science have multiple editors, fewer women serve as editors for these journals. In essence, our results show that women are more likely to serve as single editors rather than as part of a team.

Many journals have a group of associate editors who handle the review process and provide expert advice to the editors in the decision-making process. In table 2 , in the row entitled "editors and associate editors," we expand our count to include individuals with the title of associate editor. With this expansion, there are 150 people who hold the title of editor or associate editor, and the percentage of women involved in the decision making process increases from $18 \%$ to $23 \%$, which is quite close to the proportion of senior women in the profession and at $\mathrm{PhD}$-granting institutions. There are 37 men and 18 women with the title of associate editor, indicating that women are $33 \%$ of the associate editors. It is noteworthy that women are almost twice as likely to have the title of "associate editor" than the title of "editor," but the number of journals with no women drops from 32 to 25 out of the 50 journals on the list. Half of the top 50 journals in political science have at least one woman as an editor or associate editor.

The impact of including associate editors in our analysis varies from journal to journal. Relatively few, only 13, journals have associate editors. For example, the American Political Science Review does not use associate editors. The Journal of Conflict Resolution and Party Politics both have one. The American Journal of Political Science has six, and World Politics and the Journal of Peace Research both have the most at nine. Among the journals that have associate editors, one, Law and Society Review, has more associate editors that are women, with one man and three women, bringing their total number of all editors to one man and four women. One other journal, the American Journal of Political Science, has gender parity among its associate editors, with three men and three women, bringing their total editorial staff to four men and three women. World Politics has five male and four female associate editors. In contrast, the Journal of Peace Research has eight men and one woman. Four of the journals with associate editors had no women in that position.

For seven journals, the inclusion of associate editors increases the percentage of women editors on their staffs, and for some, dramatically. The American Journal of Political Science increases their representation of women from o\% to $43 \%$, World Politics increases from $0 \%$ to $40 \%$, and Philosophy and Public Affairs increases from $0 \%$ to $33 \%$. For two journals, the inclusion of associate editors decreases the representation of women. International Studies Quarterly, which has one male and one female editor, declines from an editorial staff of $50 \%$ women to $20 \%$ women with the addition of associate editors. Law and Society Review, with a single female editor, declines from a 100\% female editorial staff to $80 \%$. For four journals with associate editors, they still had no women represented in their editorial decisionmaking process.

The presence of a female editor does not appear to be related to increasing the number of female associate editors. Only three of the journals that have associate editors had female editors. International Studies Quarterly has one male and one female editor, and three male associate editors. Public Opinion Quarterly has one male and one female editor, and one male and one female associate editor. Only Law and Society Review has an editorial staff led by a female editor, with one male and three female associate editors. None of the journals headed by a single female editor employ associate editors. Thus, while the proportion of women who have reached senior ranks is reflected in the proportion of women who serve as editors and associate editors overall, there is a great deal of variation across journals.

In the final row of table 2, we include data on the number of editorial and advisory board members. The names of these boards vary, but include "Editorial Board," "Editorial Committee," "Senior Advisors," and "Advisory Board." Because some journals have more than one such group, as we compiled the data, we counted all men and women serving on these boards or committees, recognizing that their roles and influence might differ, but that serving on them is a form of professional recognition. The role of board members varies but can include work such as refereeing articles, providing expert advice on the caliber of manuscripts, participating in the decision-making process about the future direction of the journal, and soliciting article submissions. In some cases, the board members serve in honorary roles where their names elevate the prestige of the journal.

All of the journals, except for the Journal of Law and Economics, have some type of board or editorial committee. For journals with boards, the average size is 36 members. International Studies Quarterly has the highest number, with 100 editorial board members. Comparative Politics has the smallest, with only five members on its editorial committee. Editorial and advisory boards present an opportunity for journals to select a diverse group of scholars to provide guidance and to raise the profile of the journal, with more than 1,700 people holding these positions at the top 50 political science journals. Indeed, we see greater representation of women when we look at the composition of these boards, with women making up $26 \%$ of all board members. Although editors and associate editors are typically senior-level faculty, occasionally highly productive junior faculty are invited to serve on these boards. Given this, the percentage of female board members comes close to the percentage of all female faculty, $29 \%$, and the percentage of female faculty at $\mathrm{PhD}$-granting institutions, $27 \%$.

Overall women are reasonably well represented on editorial boards in proportion to their presence in the discipline, yet the gender composition on specific boards varies substantially. Of the 50 journals, 15 have less than $20 \%$ female representation on their boards, with the History of Political Thought ranking the lowest with no women on its 12-member consulting editors board. At the other end of the spectrum, seven journals come close to gender parity, with more than $40 \%$ of their board members as women, including the Journal of Politics, Perspectives on Politics, PS, and Law and Society Review. One journal, the Canadian Journal of Political Science, has 10 men and 10 women on its advisory board. 
No relationship between having a high percentage of women editors and having a board with a high percentage of women is apparent. Among the seven journals with the most women on their boards, three have no women as editors or associate editors. In contrast, Politics and Society has only one female editor and a board that is comprised of $44 \%$ women. There is little evidence that having a diverse board is systematically used as a strategy to balance out an all-male editorial team. For journals with no female editors, the percentage of women on their boards ranges from $11 \%$ to $49 \%$ and averages $25 \%$. This percentage is just slightly lower than the overall average, in which women are $26 \%$ of an editorial or advisory board.

One journal stands out on our list for having achieved gender parity in all of its positions, the Canadian Journal of Political Science. This journal has one male and one female editor and, as mentioned above, an equal number of men and women on its board. As the journal of the Canadian Political Science Association and the Société québécoise de science politique, each association selects one co-editor, and each co-editor nominates editorial board members subject to the respective association's approval. While neither the associations nor the journal has an explicit policy dictating gender parity, the current co-editors have consciously worked to achieve this. They have also paid attention to regional and subfield representation on the board. ${ }^{5}$

Two journals devoted to publishing research about women and politics did not appear on the top ranked list, but merit mention here. As one would expect, journals devoted to scholarly research on women in politics have strong representation of women in editorial positions. Launched in 2005, Politics \& Gender, the offcial journal of the Women and Politics Research Section of the American Political Science Association, has two women serving as editors. Four of the five associate editors are women. The editorial board has 31 members, with 28 , or $90 \%$, women. Out of the 38 people on the entire editorial staff, four are men. The Journal of Women, Politics \& Policy (formerly Women \& Politics), also has two female editors. Its board has 36 members; 34 , or $94 \%$, are women. Of the 38 people on this journal's entire editorial staff, two are men.

\section{DISCUSSION}

The editor and editorial board data presented here provide us with a 2010 snapshot of women's inclusion in the central decision making processes of the field's premier journals. It is encouraging that, on average, women are reasonably well represented in editorial positions in proportion to the ranks they hold in the profession overall and at $\mathrm{PhD}$-granting institutions. Interestingly, women are more likely to serve as single editors than as part of a team; as the number of editors at a journal increases, it appears that the proportion of women decreases. Moreover, tremendous variation in the presence of women as editors and on editorial and advisory boards exists across journals.

In our informal conversations with journal editors, it is clear that editors are very aware of the importance of having diverse editorial staffs. However, our analysis of the representation of women in editorial positions further underscores some of the barriers that have been identified as hindering women's upward mobility in the academia. First, journal editors and board members use their social and professional networks to solicit journal submissions. While male and female editors are likely to encourage both male and female scholars to submit their research to the journal, it seems likely that on average, male editors will reach out to more men, and female editors will reach out to more women. If the editors and the overwhelming majority of board members are men, then fewer women may receive that "critical nudge" to submit their work to the journal. As anecdotal evidence of this, the co-editor of the Canadian Journal of Political Science noted new submissions from female scholars have increased since 2006, when the journal made the decision strive for gender parity.

Second, women in editorial positions serve as role models for graduate students and junior faculty members. Younger scholars see that professional advancement opportunities exist for them and that the profession is open to different perspectives and leadership styles. Certainly both men and women can serve as mentors although seeing someone "like you" in these prestigious roles is crucial. As we consider the advancement of women in our field, the presence of women in leadership positions, such as journal editors, might encourage junior female scholars and graduate students to stay in academia (see for example, Campbell and Wolbrecht 2006; Smith and Owen 2006; Wolbrecht and Campbell 2007).

Third, editors, associate editors, and board members serve as the gatekeepers to what research gets published and as such, they have a substantial influence in determining the future direction of our discipline. Through their decisions, editors determine the "important" research questions, the "appropriate" methodological tools, and the "worthwhile" perspectives. Greater inclusion of women and others who bring different perspectives to research could result in a more vibrant range of research topics and methodological approaches published in a journal.

Although our analysis here provides a preliminary discussion of the editorial composition of political science journals, it also raises some important questions. What explains the tremendous variation across journals? What can journals do to address gender imbalances in their editorial leadership? As a starting point, we offer a few suggestions, while recognizing that more research is needed to identify best practices and explore current procedures at the journals where women have relatively high representation. The Canadian Journal of Political Science can serve as one model, in that its editors made a deliberate decision to create a board that is $50 \%$ men and $50 \%$ women, which interestingly, actually over-represents women relative to their numbers in the profession. This approach, however, relies on editors being aware and committed to gender parity. Another possibility is that for journals affiliated with a professional association, the association executive committees or women's caucuses could advocate for higher representation of women on these journal boards.

Editors want accomplished scholars to serve as associate editors and as board members, but they might also think more broadly about the types of scholars who could serve the journal well. For example, Collins et al. (2010) found that political science faculty members at non-PhD-granting institutions represented $16 \%$ of authors in 26 political science journals between 2000 and 2007, but that in 2008 they composed just $9 \%$ of the editorial board members. While some men and women may not have published as many articles in as many prestigious journals because of higher teaching loads, university service, or family commitments, they could bring other skills and perspectives to editorial positions. Thus, as editors invite scholars to join their boards, they might consider the range of attributes that would benefit their journal as well as the future of the discipline. 


\section{NOTES}

Note: An earlier version of this article was presented at the Southern Political Science Association Meeting, New Orleans, January 2011, as part of the roundtable "Getting on a Journal Editorial Board." This paper benefitted greatly from the audience questions and the insights provided by the journal editors on the panel: Wendy Gunther-Canada, Jan Leighley, Bill Mishler, and Carol Weissert. Special thanks to Ayn Wisler and Eva-Marie Etzel for their assistance in compiling the editorial board documentation and coding the members. The authors also wish to thank the anonymous reviewers for their valuable suggestions.

1. The one exception is the Public Administration Review, where the board of editors information was found on-line in November 2010 through the American Society for Public Administration website.

2. For details on how the 92 journals were selected, please see Garand et al. (2009), p. 697.

3. One journal, Public Opinion Quarterly, has section editors in addition to editors and associate editors, which are not included in our count.

4. We realize the limitations of simply comparing percentages and have tried to qualify our conclusions throughout the analysis. If we assume that those selected to be editors and board members are a random draw from all senior professors, it is statistically possible that the proportion of women drawn from the sample is not going to match the proportion of women in the general population. For example, the distribution of women for a sample of 95 editors should have a mean of 0.25 and a standard error of 0.039 . The t-score associated with our finding of $18 \%$ women is -1.308 . This has a probability of 0.097 in a one-tailed test, which does not meet the 0.05 significance level to conclude that women are underrepresented. In other words, it is possible that a random draw of 95 editors from a population that is $25 \%$ female would produce a sample that is $18 \%$ female. (We thank an anonymous referee for clarifying this.)

5. This information comes from email communication on December 18,2010 between the authors and Csaba Nikolenyi, one of the two co-editors, about the journal's practices.

\section{REF E R E N C E S}

American Political Science Association, 2010. Data on women in political science. Campbell, David E., and Christina Wolbrecht. 2006. "See Jane Run: Women Politicians as Role Models for Adolescents." Journal of Politics 68 (2): 233-47.

Collins, Todd A., Christopher A. Cooper, and H. Gibbs Knotts. 2010. "Scholarly Productivity in Non-PhD Departments." PS: Political Science and Politics 43: 509-14.

Garand, James C., Micheal W. Giles, André Blais, and Iain McLean. 2009. "Political Science Journals in Comparative Perspective: Evaluating Scholarly Journals in the United States, Canada, and the United Kingdom." PS: Political Science and Politics 42: 695-717.

Kennedy, Barbara L., Ying Lin, and Leah J. Dickstein. 2001. "Women on the Editorial Boards of Major Journals." Academic Medicine 76 (8): 849-51.

Metz, Isabel, and Anne-Wil Harzing. 2009. "Gender Diversity in Editorial Boards of Management Journals." The Academy of Management Learning and Education 8 (4): 540-57.

Morton, Melinda J., and Seema S. Sonnad. 2007. "Women on Professional Society and Journal Editorial Boards." Journal of the National Medical Association 99 (7): 764-71.

Sedowski, Leanne, and Michael Britnall. 2007. Data Snapshot: The Proportion of Women in the Political Science Profession. Washington, DC: American Political Science Association.

Smith, Walter S., and Thomas Owen. 2006. "Effect of Women Science Career Role Models on Early Adolescents' Attitudes toward Scientists and Women in Science." Journal of Research in Science Teaching 23 (8): 667-76.

"Women's Advancement in Political Science: A Report on the APSA Workshop on the Advancement of Women in Academic Political Science in the United States." Washington, DC: American Political Science Association (2005). Available online at: http://www.apsanet.org/imgtest/womeninpoliticalscience.pdf

Wolbrecht, Christina, and David E. Campbell. 2007. "Leading by Example: Female Members of Parliament as Political Role Models." American Journal of Political Science 51 (4): 921-39.

\section{APPENDIX: Editors and Editorial Board Compositions, 2010}

\begin{tabular}{|c|c|c|c|c|c|c|c|c|c|}
\hline \multirow[b]{2}{*}{ JOURNAL NAME } & \multicolumn{3}{|c|}{ EDITORS } & \multicolumn{3}{|c|}{ EDITORS \& ASSOCIATE EDITORS } & \multicolumn{3}{|c|}{ BOARD MEMBERS } \\
\hline & Men & Women & Percent Women & Men & Women & Percent Women & Men & Women & Percent Women \\
\hline American Journal of Political Science & 1 & 0 & 0 & 4 & 3 & 42.9 & 42 & 23 & 35.4 \\
\hline American Political Science Review & 7 & 1 & 12.5 & 7 & 1 & 12.5 & 45 & 26 & 36.6 \\
\hline American Politics Research & 1 & 0 & 0 & 1 & 0 & 0 & 25 & 11 & 30.6 \\
\hline Annals of the American Academy & 0 & 1 & 100 & 0 & 1 & 100 & 17 & 9 & 34.6 \\
\hline British Journal of Political Science & 2 & 1 & 33.3 & 2 & 1 & 33.3 & 34 & 7 & 17.1 \\
\hline Canadian Journal of Political Science & 1 & 1 & 50 & 1 & 1 & 50 & 10 & 10 & 50 \\
\hline Comparative Political Studies & 1 & 0 & 0 & 1 & 0 & 0 & 26 & 3 & 10.3 \\
\hline Comparative Politics & 2 & 0 & 0 & 2 & 0 & 0 & 4 & 1 & 20 \\
\hline Electoral Studies & 3 & 0 & 0 & 3 & 0 & 0 & 41 & 5 & 10.9 \\
\hline European Journal of International Relations & 2 & 1 & 33.3 & 2 & 1 & 33.3 & 43 & 7 & 14 \\
\hline European Journal of Political Research & 2 & 0 & 0 & 2 & 0 & 0 & 24 & 8 & 25 \\
\hline \multicolumn{10}{|l|}{ Foreign Affairs* } \\
\hline Governance & 2 & 0 & 0 & 2 & 0 & 0 & 21 & 5 & 19.2 \\
\hline Government and Opposition & 1 & 1 & 50 & 1 & 1 & 50 & 41 & 10 & 19.6 \\
\hline History of Political Thought & 1 & 1 & 50 & 1 & 1 & 50 & 12 & 0 & 0 \\
\hline International Affairs & 0 & 1 & 100 & 0 & 1 & 100 & 16 & 2 & 11.1 \\
\hline International Organization & 2 & 0 & 0 & 4 & 0 & 0 & 26 & 11 & 29.7 \\
\hline International Political Science Review & 1 & 1 & 50 & 1 & 1 & 50 & 15 & 4 & 21.1 \\
\hline International Security & 3 & 0 & 0 & 3 & 0 & 0 & 37 & 8 & 17.8 \\
\hline International Studies Quarterly & 1 & 1 & 50 & 4 & 1 & 20 & 74 & 26 & 26 \\
\hline
\end{tabular}

(continued) 


\section{APPENDIX (Continued)}

\begin{tabular}{|c|c|c|c|c|c|c|c|c|c|}
\hline \multirow[b]{2}{*}{ JOURNAL NAME } & \multicolumn{3}{|c|}{ EDITORS } & \multicolumn{3}{|c|}{ EDITORS \& ASSOCIATE EDITORS } & \multicolumn{3}{|c|}{ BOARD MEMBERS } \\
\hline & Men & Women & Percent Women & Men & Women & Percent Women & Men & Women & Percent Women \\
\hline Journal of Common Market Studies & 2 & 0 & 0 & 2 & 0 & 0 & 20 & 8 & 28.6 \\
\hline Journal of Conflict Resolution & 1 & 0 & 0 & 2 & 0 & 0 & 23 & 7 & 23.3 \\
\hline Journal of Democracy & 2 & 0 & 0 & 2 & 0 & 0 & 50 & 10 & 16.7 \\
\hline Journal of European Public Policy & 1 & 0 & 0 & 1 & 0 & 0 & 36 & 10 & 21.7 \\
\hline Journal of Law and Economics & 4 & 0 & 0 & 4 & 0 & 0 & & & \\
\hline Journal of Peace Research & 1 & 0 & 0 & 9 & 1 & 10 & 32 & 5 & 13.5 \\
\hline Journal of Politics & 1 & 1 & 50 & 1 & 1 & 50 & 45 & 32 & 41.6 \\
\hline Journal of Theoretical Politics & 2 & 0 & 0 & 2 & 0 & 0 & 33 & 10 & 23.3 \\
\hline Law and Society Review & 0 & 1 & 100 & 1 & 4 & 80 & 22 & 16 & 42.1 \\
\hline Legislative Studies Quarterly & 3 & 0 & 0 & 3 & 0 & 0 & 19 & 7 & 26.9 \\
\hline Party Politics & 3 & 0 & 0 & 4 & 0 & 0 & 31 & 6 & 16.2 \\
\hline Perspectives on Politics & 1 & 0 & 0 & 1 & 0 & 0 & 8 & 6 & 42.9 \\
\hline Philosophy and Public Affairs & 1 & 0 & 0 & 4 & 2 & 33.3 & 14 & 2 & 12.5 \\
\hline Political Analysis & 2 & 0 & 0 & 4 & 1 & 20 & 26 & 7 & 21.2 \\
\hline Political Behavior & 2 & 0 & 0 & 2 & 0 & 0 & 19 & 6 & 24 \\
\hline Political Psychology & 3 & 1 & 25 & 3 & 1 & 25 & 21 & 10 & 32.3 \\
\hline Political Research Quarterly & 1 & 1 & 50 & 1 & 1 & 50 & 37 & 20 & 35.1 \\
\hline Political Science Quarterly & 1 & 0 & 0 & 1 & 0 & 0 & 25 & 3 & 10.7 \\
\hline Political Studies & 2 & 0 & 0 & 5 & 2 & 28.6 & 25 & 8 & 24.2 \\
\hline Political Theory & 0 & 1 & 100 & 0 & 1 & 100 & 25 & 8 & 24.2 \\
\hline Politics and Society & 0 & 1 & 100 & 0 & 1 & 100 & 9 & 7 & 43.8 \\
\hline Polity & 1 & 0 & 0 & 1 & 0 & 0 & 17 & 16 & 48.5 \\
\hline PS: Political Science and Politics & 1 & 0 & 0 & 1 & 0 & 0 & 8 & 7 & 46.7 \\
\hline Public Administration Review & 1 & 0 & 0 & 1 & 0 & 0 & 27 & 14 & 34.1 \\
\hline Public Choice & 3 & 0 & 0 & 3 & 0 & 0 & 41 & 6 & 12.8 \\
\hline Public Opinion Quarterly & 1 & 1 & 50 & 2 & 2 & 50 & 25 & 8 & 24.2 \\
\hline Review of International Studies & 1 & 0 & 0 & 5 & 1 & 16.7 & 18 & 8 & 30.8 \\
\hline Social Science Quarterly & 1 & 0 & 0 & 1 & 0 & 0 & 41 & 19 & 31.7 \\
\hline West European Politics & 2 & 0 & 0 & 2 & 0 & 0 & 22 & 8 & 26.7 \\
\hline World Politics & 1 & 0 & 0 & 6 & 4 & 40 & 16 & 7 & 30.4 \\
\hline Total & 78 & 17 & 17.9 & 115 & 35 & 23.3 & 1288 & 457 & $26.2^{* *}$ \\
\hline
\end{tabular}

*Because Foreign Affairs has a different editorial structure than other political science journals, we exclude it from our analysis. The journal's editorial leadership comes from the journalism field rather than political science academic positions.

**Note that some individuals serve on more than one editorial board. While there are a total of 1288 men and 457 women on editorial boards, some of these individuals are counted more than once. 